\title{
Ulus-Devlet İnşa Sürecinde Kadınların Siyasal Hakları: Türkiye'de Seçme-Seçilme Haklarına İlişkin Tartışmalarda Sömürgecilik Sonrası Söylemin İzleri
}

The Relationship Between Nation-State and Women's Political Rights: The Parliament Discussions on Political Rights in 1934 and Post-Colonial Discourse

\section{Elif Gazioğlu Terzi}

\section{$\ddot{O} z$}

Ulus-devlet inşa süreçlerinde kadınların siyasal haklarına yönelik iki temel tutum gözlenir. Bunlardan ilki, kadınların vatandaşlıktan dışlandıkları ve kamusal mevcudiyetlerinin sınırlandırıldığı yaklaşımdan beslenirken; ikincisi, kadınları erkeklerle eşit vatandaşlar olarak kabul eder. Bu çalışma, 1934 yılındaki genç Türkiye siyasetinde egemen olan yaklaşımın, daha çok sömürgecilik sonrası kurulan ulus-devletlerde gözlenen, kadınların eşit vatandaşlar olarak kabul edildiği yaklaşıma yakınlığını ortaya koyarken, bu yaklaşımın çoğunlukla, kadınların hak mücadelelerini görmezden gelen ve onları ulusdevlet inşa sürecinden dışlayan "kadınsız" bir bağlamda gerçekleştiğine işaret etmektedir. Makale, Türkiye'de kadınların seçme ve seçilme haklarının tanındığı tarih olan 5 Aralık 1934’teki meclis tartışmalarını incelemekte ve bu tartışmalara hâkim olan söylemleri mercek altına almaktadır. Nihayetinde çalışma, Türkiye'de ulus-devletin inşa ettiği toplumsal cinsiyet rejimine meşruiyetini sağlayan söylem ile sömürgecilik sonrası söylem arasındaki benzerliklere ışık tutmaktadır.

Anahtar Kelimeler: Ulus-Devlet, Toplumsal Cinsiyet, Kadınların Siyasal Hakları, Sömürgecilik Sonrası Söylem

Yrd. Doç. Dr., Ardahan Üniversitesi, İktisadi ve İdari Bilimler Fakültesi, Kamu Yönetimi Bölümü, elifgazioglu@ardahan.edu.tr

Bu makale iThenticate sistemi tarafından taranmıştır.

Makale gönderim tarihi: 22.06.2015

DOI: $10.17550 /$ aid.28218 


\begin{abstract}
Focusing on the relationship between nation-state and women's demands of political rights, this paper aims to understand this relationship during the construction of Turkish Republic. Drawing upon an in-depth investigation on the Turkish parliamentary records of December 5, 1934 when women gained their political rights as equal citizens, this paper looks at the parliamentary discussions on women's rights and equal citizenship in gender equality context. It aims to highlight the similarities between the young Turkish nation-state's discourse on women's political rights and the post-colonial approach to the issue.
\end{abstract}

Keywords: Nation-State, Gender, Women's Political Rights, Post-Colonial Discourse 


\section{Giriş}

Türkiye'nin ulus-devletleşme sürecini kadın bakış açısıyla analiz eden birkaç önemli çalışma dışında süreci, kadınları dâhil ederek okuyan çalışma yok denecek kadar azdır. ${ }^{1}$ Sosyal bilimlere uzun yıllar boyunca yön vermiş olan, kadınları dışlayan/yok sayan yaklaşım, Türkiye'ye özgü değildir. Tarihsel olay, olgu ve süreçlerin erkekler tarafından tespit edilmesi, günümüze aktarılması ve yorumlanmasının uzun bir geçmişi olduğu kadar, çok geniş bir coğrafyaya yayılmış olduğu da bilinmektedir.

Erkeğin tarihsel bilginin tek üreticisi ve aktarıcısı olduğu kabulü, geleneksel sosyal bilimler anlayışına hâkim olan, bilgi ve kadınlığın birbirini dışladığına dair inanca dayanmaktadır. Geleneksel anlayış, bilginin üreticileri/özneleri olarak kabul etmediği kadınları, bilginin nesnesi konumuna indirger (Cook and Fonow, 1990: 73; Jaggar, 2008: 35). Bu yaklaşımdan beslenen geleneksel tarih anlayışının doğurduğu temel sakıncaları şöyle sıralamak mümkün görünmektedir: Kadınları dışlayan bir tarih anlatısı, sözü edilen süreçlerde kadınların yer almadığı algısını yaratmaktadır. Örneğin, modern Türkiye'nin kuruluş aşamasında özellikle kadın hareketlerinin süreç içindeki konumlarının günümüze aktarılmaması, kadınların kuruluş sürecinde oynadıkları rolün yok sayılması ya da daha iyimser bir yorumla azımsanması anlamına gelecektir. Oysa hem Türkiye özelinde hem de küresel ölçekte kadınlar, ulus-devlet inşa süreçlerine bir şekilde müdahil olmuşlardır. $\mathrm{Bu}$, Türk Kadınlar Birliği (TKB) ${ }^{2}$ örneğinde olduğu üzere, örgütlü bir siyasal hak talebi ile kurucu kadrolar üzerinde baskı oluşturma amacıyla hareket etmek şeklinde olabildiği gibi; Tanzanya örneğinde olduğu üzere, "annelik hakkı" söylemi ile süreç içinde yer alma mücadelesi şeklinde olabilmiştir (Chadya, 2003).

Kadınları yok sayan yaklaşım, tarihin sadece egemenlerin gözünden aktarılmasına neden olacağı için, bilinçli olarak manipüle edilmiş bir tarih bilgisini önümüze serer. Örneğin "kadınlar haklarını Atatürk'e borçlu" şeklindeki resmi tarih anlatısı, egemen devletin ko-

1 Az sayıdaki önemli çalışmadan bazıları için bkz. Durakbaşa, 2000; Sancar, 2014; Zihnioğlu, 2003.

2 İlerleyen sayfalarda TKB'ye ilişkin ayrıntılı bilgi verilmektedir. 
nuya ilişkin yaklaşımını ortaya koymakla kalmaz, aynı zamanda kadınların hak mücadelesini yok saydığı ölçüde, kadınlara dair edilgenlik algısını meşrulaştıran bir araca, bir stratejiye dönüşür. Kadınların yok sayılmasının bir başka sakıncası da, resmi tarih anlatısının sonuçlarıyla bağlantılı olarak, diğer sosyal bilimler gibi tarihin de tek bakış açısından yazılması ve yorumlanması, gerçekliğin yalnızca bir yüzünün, o da bilinçli/politik bir körlüğün yansıması olan bir yüzünün günümüze aktarılması anlamına gelecektir. Böylesi bir tek boyutlu, çarpıtılmış tarih anlayışı yalnızca geçmişe dair algıları manipüle etmekle kalmaz aynı zamanda kadınların bugün verdikleri mücadelelerin de görünmez kalmasına ya da değersiz görülmesine neden olur (Westkott, 1990:59).

Tarihsel sürecin, kadınlara yer vermeyen aktarımını ve yorumunu, kadının toplumsal konumunun bir yansıması olarak okumak mümkündür. Esasında bu iki olgu, "kadınsız tarih" ve kadının ikincil statüsü, birbirini oluşturan ve besleyen olgulardır. Bu durum en net ifadelerinden birine, bu çalışmanın çekirdeğini oluşturan 1930'lu yılların millet meclisinin cinsiyet profilinde kavuşur. 1935 yılına kadar mecliste hiç kadın vekil yoktur ve dolayısıyla kadınları ilgilendiren çok önemli bir tartışmada, yeni devlette kadınların seçme ve seçilme hakkı tartışmasına kadınlar müdahil olamamışlardır. Yine de kadınların, kendilerinin yer almalarına izin verilmeyen böylesi bir tartışmaya, meclise gönderdikleri teşekkür içerikli mektuplarla ${ }^{3}$ da olsa dâhil olmanın yollarını aramış oldukları görülmektedir.

Resmi tarih anlatısının kadınların dâhil olduğu gelişmeleri anlatma/aktarma konusundaki isteksizliği dolayısıyla, kadınların sürece mektup ve benzeri araçlarla müdahil olma çabalarına da ancak meclis tutanaklarının taranmasıyla ulaşmak mümkün olmaktadır. Burada, analiz kaynağı olarak meclis tutanaklarına dair bir parantez açmakta yarar vardır. Genç ulus-devletin niteliğine ve işleyişine dair önemli ayrıntıların satırlara döküldüğü belgeler olmalarının yanı sıra meclis

3 Örneğin, Ankara Halkevi'ndeki kadınlar adına meclise gönderilen 6 Aralık 1934 tarihli mektupta şöyle denilmekteydi: “Türkiye Büyük Millet Meclisi Yüksek Başkanl1ğına; Dün Büyük Millet Meclisi Türk kadınlarının saylav seçmek, saylav seçilmek kanununa onay verdi. Biz Türk kadınları bundan gönenç duyduk. Gerekli olan iş yapıldı. Türk kadım bundan sonra daha eyi anlaşılacaktır. Bu hakikati anlayan, ortaya koyan, kanunla teyit eden Büyük Türk Ulusunun mümessillerine minnet.” (TBMM ZC, c.25, I. 4 , s. 90). 
tutanakları, yeni rejimin kurma amacında olduğu toplumsal cinsiyet rejimine ${ }^{4}$ dair de çok önemli veriler sunmaktadır. Bu anlamda, ayrıntılı tarihsel çalışmalar için oldukça verimli kaynaklardır. Nitekim son yıllarda Türkiye'de sosyal bilimler alanında yapılan çok sayıda araştırma, kaynağını meclis tutanaklarında bulmuştur (örn. Alpaslan, 2013; Bayrak, 2007; Yaramiş, 2012). Meclis tutanaklarına dayanan çalışma sayısının çokluğu ve niteliğinin çeşitliliğine karşın, tutanaklarda kadınları arayan ya da belgeleri kadın bakış açısıyla analiz etme iddiasında olan araştırma yok denecek kadar azdır. Dahası, uluslararası literatürde oldukça dikkat çeken bir konu olarak ulus-devlet ile kadın hakları arasındaki ilişkinin niteliğini ortaya koyacak politik söylemin tutanaklardan izlenmesi Türkiye'de gerekli ilgiyi görmemiştir. Oysa meclis tutanakları resmi ve politik söylemlerin aranabileceği temel basılı metinler arasında yer almaktadır. Karmaşık yapısı, ideolojik çeşitliliği, barındırdığı kültürel çoğulluk ve yaslandığı tarihsel arka plan dolayısıyla meclis, toplumun bir yansımasıdır. Aynı zamanda, hâkim siyasal kurum olarak da toplum üzerinde yönlendirici etkisi söz konusudur. $\mathrm{Bu}$ anlamda mecliste konuşulanların kayıt altına alındığı tutanaklar, bu karşı1lklı etkileşimin ne tür bağlamlarda gerçekleştiğini anlamak açısından önemli kaynaklardır. Bir başka ifade ile devletin ve resmi söylemin şekillendiği, bir anlamda vücuda geldiği kurum olarak millet meclisinin sözü, toplumsal yapıya şekil veren ve aynı zamanda bu yapı tarafindan şekillenen söz olarak kayda geçmektedir. Bu bağlamda bu çalışma, ulus-devletin erken döneminde kendi toplumsal cinsiyet rejimini inşa etmekte olan genç Cumhuriyet'in resmi söyleminin vücut bulduğu 1934 yılı meclis tutanaklarına odaklanmaktadır. Makalenin izleyen bölümlerinde, öncelikle ulus-devlet ile kadınlar arasındaki gerilimli ilişkiye dair tartı̧̧malar özetlenecek, ardından kadınların siyasal hakları bağlamında dönemin Türk siyasi hayatına hâkim olan söylemin tarihsel ve toplumsal köklerini ortaya koymak amacıyla, konuya ilişkin sömürgecilik sonrası yaklaşıma değinilecek ve sonrasında meclis içi tartışmaların bu bağlamdaki analizine geçilecektir.

4 Toplumsal cinsiyet kavramı kadınlık ve erkekliği, bireylerin biyolojik özellikleri ile değil, bu özelliklere toplum tarafından yüklenen anlam ve dayatılan rollerle açıklar. Buna göre kadınlık ve erkeklik zamana ve mekana göre değişen toplumsal ve tarihsel olgulardır. Toplumların cinsiyetlere yönelik alg1 ve tutumları ile bu algı ve tutumların şekillendirdiği roller genel olarak o toplumlarda egemen olan cinsiyet rejimlerini oluştururlar. 


\section{Eril Tahayyül Olarak Ulus-Devlet ve Feminist Eleștirisi}

Benedict Anderson (1991) ulusu tahayyül edilmiş bir topluluk olarak tanımlar. Bu tahayyülün birkaç bileşeni vardır. Ulus, öncelikle, hayal edilmiş bir topluluktur çünkü birbirini tanımayan, hayatlarında bir kez olsun karşılaşmamış insanların birliğini, ortaklığını varsaymaktadır (2007: 20). Bu anlamıyla ulus bir icat ya da yaratım değil, uydurma, kandırmaca olarak düşünülmelidir. Bir diğer bileşen, sınırlardır. Anderson'a göre ulus, sınırlı bir birim olarak hayal edilmektedir, insanlığın tümünü kapsamak gibi bir iddiası yoktur. Tersine bir grup insanın diğerlerinden ayrılı̆̆g/farklılı̆̆ 1 üzerinden var olur. Dolayısıyla sınır, bu tarafi o taraftan ayırdığı sürece ulusun bileşeni olur, farklı uluslardan insanları ayırdığı sürece ulusun varlığında ve devamlılığında etkili olur. Bir diğer bileşen olarak egemenlik, ulusun diğer tüm toplumsal ve siyasal aktörler karşısında takındığı üstünlük iddiasının adıdır. $\mathrm{Bu}$ iddia egemen devlette vücut bulur. Egemen devlet, ulusun kurucusu ve koruyucusudur. Anderson'a göre son olarak ulus, bir cemaat, bir topluluk olarak hayal edilir. Zira kendi ifadeleriyle; "her ulusta fiilen geçerli olan eşitsizlik ve sömürü ilişkileri ne olursa olsun, ulus daima derin ve yatay bir yoldaşlık olarak tasarlanır. Son iki yüzyıl boyunca milyonlarca insanın, birbirlerini öldürmekten çok, böylesi sınırlı hayaller uğruna ölmeye razı olmalarını mümkün kılan şey son kertede bu kardeşlikti[r].” (2007: 22).

Anderson tezini yayınladıktan bir süre sonra feminist çalışmalar, onun sözünü ettiği yoldaşlı̆ğı/kardeşliğin kimler arasında kurulduğunu sorgulamaya başladılar; ulusu tahayyül edenler kimlerdi? (Enloe, 1989; 2013; Mayer, 2000; McClintock, 1995; McDowell, 1999) $\mathrm{Bu}$ sorundan hareketle, teze yöneltilen temel eleştiri, ulusun yapıcıları ve koruyucularının erkek olduğunu varsayıyor oluşuydu; sözünü ettiği kardeşlik, erkek kardeşlikti. Esasında eril bir karakter taşıyan bu dayanışma ilişkisi, cinsiyetsizmiş gibi sunulduğu için, bir taraftan kadının, ulus içindeki dışlanmışlığı, ötekileştirilmişliği de görünmez hale gelirken, diğer taraftan da toplumsal cinsiyetin ulus inşasındaki başat konumu önemsizleştirilmekteydi (McClintock, 1995: 353). Mesele, ulusun tanımından ya da inşası sürecinden ibaret değildi; ulus pratiğinin içindeki iktidar ilişkilerinin niteliği ve bu ilişkilerin üretilmesi ve yeniden üretilmesi de toplumsal cinsiyet rejimleriyle birebir bağlantılıydı (McDowell, 1999). Kadınların, ulus-devletlerin, teoride 
kurucu ideolojilerinden, pratikteyse kurucu kadrolardan nasıl dışladıklarına - ya da sürece nasıl ve ne derece katılabileceklerinin sınırlarının belirlendiğine- dair bu tespitler, ulusun, eril tahayyülün bir yansıması olduğu tezini doğruluyordu. Bu teze göre, ulus-devlet inşası sürecinde kadınların dışlanmadıkları yegane alan, sembolik alandır (Kaminsky, 2007; Omar, 2004; Riedner, 2013). Özellikle, ulus-devletin kurucu ideolojisi olan milliyetçiğin retorik bağlamında okunması, ulus inşasında kadınlara -ve belki de daha doğru bir anlatımla, kadınlığa- yüklenen sembolik rolü göz önüne sermektedir. Bu anlamda dil ve vatan gibi kavramların ulusal değerlerle yüklenerek "anadil" ve "anavatan" gibi adlara kavuşturulmaları ya da benzer şekilde, ulusun sembollerinin, Kuzey Amerika'nın özgürlük heykelinde olduğu gibi, açıkça kadın cinsiyeti taşımaları rastlantı değildir (Omar, 2004: 49).

Ulusu eril tahayyülün yansıması olarak okumak, yalnızca onun içerdiği/kurduğu toplumsal cinsiyet rejimlerini görünür kılmakla kalmaz. Bunu yapmak, ulusu yalnızca bir kavram olarak anlayabilmek için değil aynı zamanda mevcut ulusal pratiklere dair doğru bir kavrayış geliştirebilmek için de elzemdir çünkü ulusun kim tarafından nasıl kurgulandığı, onun pratikte nasıl tecrübe edildiğini belirler. $\mathrm{Bu}$ noktada Chatterjee'nin (2005) yanıt aradığı soru önemlidir: Eril tahayyülün ürünü olarak kabul edildiğinde ulus-devlet, kadınlar tarafından nasıl algılanır, nasıl deneyimlenir? Kadınların, siyasal haklarını tanıyan, onlara erkeklerle eşit vatandaşlık statüsü sağlayan bir yapıyla yönelik algıları ile kadın haklarını tanımayan bir siyasi birlik karşısındaki tutumları kaçınılmaz olarak farklı olacaktır. Bu formülasyonu kısmen çözmüş olan ulus-devlet bugün geldiği noktada, kadınların siyasal haklarını tanıyarak onları eşit vatandaşlar olarak kabul etmiş, böylece toplumlar gözündeki meşruiyetini sağlamlaştırmıştır. Öte taraftan, eşit vatandaşlık anlayışı ile kadın hakları hareketinin amaçları arasında zaman zaman paralellikler oluşsa da ulus-devlet, kadınlar tarafından verilen kadın hakları mücadelesine olumlu yaklaşmaz. Çünkü her ulus-devlet kendi hiyerarşik toplumsal cinsiyet rejimini oluşturur ve bu rejime muhalefet eden bir eşitlik mücadelesiyle barışık olması, doğasına aykırıdır. Dolayısıyla, Anderson'ın tespitleri bir başka açıdan değerlendirildiğinde şu sonuç çıkar; ulusal birlik bir kandırmacadır çünkü esasında ulus, birliğe değil, kurumsallaşmış toplumsal cinsiyet ayrımına dayanır (McClintock, 1993). Ancak yukarıda belirtildiği gibi, 
meşruiyete ihtiyaç duyan bu siyasal birlik, kadınları eşit vatandaşlar olarak tanımak durumunda kalmıştır.

Ulus-devlet bu noktaya varana kadar çeşitli aşamalardan geçmiş, bu aşamalarda kurucu kadroların, kadınların ulus-devlet inşa süreçlerinde oynadıkları role ilişkin yaklaşımları da etkili olmuştur. Kadınların siyasal haklarına ilişkin karar ve uygulamalar da yine bu yaklaşımlardan hareketle gerçekleşmiştir. Söz konusu yaklaşımları, Batı menşeili yaklaşım ve sömürgecilik sonrası yaklaşım olarak adlandırmak mümkün görünmektedir. ${ }^{5}$ Makalenin şimdiki bölümü bu yaklaşımlara odaklanmaktadır.

\section{Kadınların Siyasal Haklarına İlişkin Sömürgecilik Sonrası Yakla- şım}

Ulus-devlet, toplumsal cinsiyet açısından tarafsız bir kurum değildir. Tersine, her ulus-devletin bir toplumsal cinsiyet rejimi vardır (Connell, 1987) ve kuruluş aşamasından itibaren bu rejimi meşru ve hâkim kılmak için çok çeşitli yaklaşımlardan beslenen çeşitli söylemlere başvurur. Fransız ve Amerikan devrimlerini izleyen süreçte, Batı coğrafyasında siyasal hayata hâkim olan anlayışa göre kadınlar, erkeklere nazaran daha sınırlı olan düşünsel kapasiteleri dolayısıyla "doğru politika" hakkında hüküm veremezler ve yine düşük zihinsel becerileri yüzünden yönetme yeteneğinden de doğaları gereği mahrumlardır (Phillips, 1995). Dolayısıyla kendilerine siyasal hakların tanınmamas1, politik olarak rasyonel, ahlaken de meşrudur. Dönemin demokrasi anlayışı için de kadınların vatandaşlıktan dışlanmaları sorun değildi. Zaten Phillips, demokrasinin eşitlik ile bağının, oldukça yakın bir tarihin ürünü olduğunu ortaya koymaktadır (1995). Nitekim söz konusu dönemde kaleme alınmış olan ve bugün de demokrasinin temel metinlerinden kabul edilen "Amerikan Bağımsızlık Bildirgesi”nde "bütün insanlar (men) eşit yaratılmışlardır" derken, erkekler arasındaki eşit-

5 Ulus-devletleşme süreçlerine ilişkin çalışmalarda önemli yer kaplayan bu iki yaklaşımdan biri "sömürgecilik sonrası yaklaşım” olarak adlandırılırken, diğerine ilişkin net bir adlandırma yoktur. Ancak, bu adlandırılmayan yaklaşım Batılı ülkelerin geçirdiği tarihsel aşamalar bağlamında ve çoğunlukla Batılı ülkelerden örneklerle açıklandığı için, anlaşılır olmak adına ben bu yaklaşımı, bu çalışma özelinde, "Batı menşeili yaklaşım” olarak adlandırıyorum. 
likten bahsetmektedir (Unanimous, 1776). ${ }^{6}$ Dolayısıyla söz konusu ülkelerde kadınlar, ulus-devlet inşa süreçlerinden dışlandıkları gibi, siyasi ve ekonomik haklardan da mahrum bırakılmış, kamusal alandaki varlıkları daha da sınırlandırılmıştır. Böylece kadınların ekonomik ve siyasal katılımını dışlayan bir demokrasi anlayışı ve uygulaması kimi ülkelerde yüz yılı aşkın bir süre boyunca egemenliğini sürdürmüştür.

Öte taraftan, doğrudan sömürge konumunda olmuş, sömürgeci güçlerin boyunduruğu altında yaşamış ve kurtuluş mücadelesi vermiş olan kimi Batılı ülkelerde durumun farklı olduğuna dair bir parantez açmak gerekmektedir. Çünkü örneğin, sömürgeci iktidarlardan bağımsızlığını elde etmesinin ardından Norveçli kadınlar, erkeklerle eşit vatandaşlar olarak kabul edilmiş; benzer şekilde Finli kadınlar, Rusya yönetimine karşı verilen mücadelenin ardından haklarına kavuşmuşlardır. Böylece Finlandiya ve Norveç, dünyada kadınların siyasal haklarını tanıyan ilk devletler olmuşlardır. Jill Vickers'a (2008: 25) göre bunun sebebi, sözü edilen devletlerin diğer Batılı devletlerden farklı olarak, sömürgeleştirilme deneyimini tecrübe etmiş olmalarıdır. Zira Vickers çeşitli ülkelerdeki kadınların, ulus-devlet inşasında oynadıkları role ve sonrasındaki konumlarına dair yaptığı çalışmada, ulus-devlet kurabilmek için öncelikle üzerlerindeki sömürgeci baskılara karşı savaşmış olan toplumların savaş sonrasında kadınlara, erkeklerle eşit vatandaşlık hakları tanıdıklarını tespit etmiştir.

Post-kolonyal döneme damga vuran, kadınların siyasal haklarına yönelik temel yaklaşım ve bu yaklaşımın vücut bulduğu "kadınlar ulusal mücadelede yer alarak vatandaşlı̆̆ 1 hak etti” şeklindeki söylem, sömürgecilik sonrası süreçte kadınların erkeklerle eşit haklara kavuşmalarının önemli dayanaklarından birini oluşturmuştur. Böylece kadınların yeni rejim tarafından eşit vatandaşlar olarak tanınmaları, ülkelerinin bağımsızlık mücadelesine katılmış olmalarıyla gerekçelendirilir (Agozino, 2014; Chaudhuri, 1999; Leonhardt, 2013). İlginç bir nokta, "hak etme" söyleminin, sözü edilen toplumlara dair akademik

6 Metinde geçen ifadenin orijinali şöyledir: "All men are created equal” (Unanimous, 1776). Metin boyunca, "insan" anlamında kullanılan "men", Anne Phillips'in (1995) işaret ettiği gibi, cinsiyetsiz bir ifade değildir. Tersine, dönemin Amerikan anayasasından takip edilebileceği üzere, mülkiyet hakkı ve seçme-seçilme hakları yalnızca erkeklere tanınmıştır. 
nitelikli çalışmalara da hâkim olmasıdır. Örneğin Biko Agozino (2014) Nijerya'nın, tarihi boyunca birçok Batılı sömürgeci güce karşı verdiği savaşta kadınların üstlendiği başat rol sayesinde erkeklerle eşit konumda bulunmayı hak ettiğini dile getirmektedir. Benzer şekilde Adrienne Leonhardt'a (2013) göre, Fransa'ya karşı verdiği mücadele sonucu bağımsızlığını kazanan Cezayir, kurtuluşunda kadınların oynamış oldukları büyük role rağmen, onlara hak ettikleri konumu sağlamamıştır.

Kadınların siyasal haklarına kavuşmalarına dair post-kolonyal bağlamda şekillenen bir diğer söylem kadınların, haklarını elde ettikleri ya da kazandıkları yerine, onlara hakların verildiğine vurgu yapan söylemdir. Böylece yeni ulus-devlet, kurmakta olduğu hiyerarşiyi ve bu hiyerarşi içinde kadınlara biçtiği aşağ 1 rolü işaret ederek kendi kudretini pekiştirirken; kurucu kadrolar da bu söylem sayesinde kendi konumlarını pekiştirmektedirler. Bu bağlamda, bir taraftan "hak edene hakkını vermek" gibi adil bir uygulamayı gerçekleştirmiş olmakla bir övünç söylemi de ortaya çıkmakta, diğer taraftan kadınlarda, onlar adına çaba gösterildiğine dair izlenim yaratılmaktadır. Her bir söyleme şekil veren hâkim yaklaşım, kadınların hak talebinde bulunmamalarına rağmen, kendilerine bu hakların devlet tarafindan verilmekte olduğu yolundaki yaklaşımdır. Hak taleplerini ve örgütlü mücadelelerini görmezden gelen bu yaklaşım, böylece, kadınların ulus-devlet inşasındaki ve takip eden süreçteki rollerini tanımak konusunda da isteksiz davranacak, hatta yok sayacaktır.

Makalenin izleyen bölümünde, kolonyal bir geçmişi olamamasına karşın genç Türkiye'nin millet meclisine hâkim olan, kadınların siyasi hakları konusundaki yaklaşımının sömürgecilik sonrası yaklaşımla benzerliği analiz edilmektedir.

\section{Meclisi'nde Kadınların Seçme ve Seçilme Hakkına Dair Tar- tışmalar}

1923 yılında Türkiye Cumhuriyeti kurulduğunda ülke, neredeyse on sene sürmüş olan bir savaştan ağır hasarla çıkmış durumdaydı. Savaşta, önemli bölümü savaşa katılan erkeklerden oluşan büyük bir nüfus hayatını yitirmiş, bazı doğu illerinde eşini kaybetmiş kadın oranı yüzde otuza yükselmişti (Zürcher, 2004: 239). Göç ve mübadelelerle birlikte gerçekleşen dramatik demografik değişimler, yeni Türkiye'nin nüfus yapısı üzerinde belirleyici olacaktı. Zürcher'in ifadeleriyle, "Nüfus 
değişiklikleri, 1913'teki Anadolu'nun 1923'teki Anadolu'dan kültürel açıdan tamamıyla farklı bir yer olduğu anlamına geliyordu" (2004: 240). Savaştan önce başlayan kentleşme süreci tersine dönmüş, savaş öncesinde nüfusun yüzde yirmi beşi kentlerde yaşarken, savaştan sonra bu oran yüzde on sekizlere düşmüştü (Zürcher, 2004: 240). Savaşın ülkeye verdiği ekonomik zarar da büyüktü. Buna rağmen ekonomi büyük oranda tarıma dayalı olduğu için ülke ekonomik anlamda hızlı bir kalkınma gerçekleştirecekti. Bu koşullarda tek parti rejimine dayalı sistemin ilk hükümeti İsmet İnönü tarafindan kuruldu ve ülke siyaseti 1950 yılındaki seçimlere kadar tek parti tarafından yönlendirildi.

Savaş döneminde, birçok ülkede olduğu gibi Türkiye'de de askere alınan erkek nüfusun emek piyasasında bıraktığı boşluğu kadınlar doldurdu. Kadınların işgücüne katılımı, dönemin kimi yazarlarınca "kadın inkılabı" olarak yorumlanacak gelişmelere vesile olurken, kimisine göre bu tür gelişmeler "aile hayatının çöküşüne" işaret etmekteydi (aktaran Zihnioğlu, 2003: 82). Ancak kadınlar emek piyasasındaki varlıklarını uzun süre devam ettiremediler. Savaşın sona ermesinin ardından evlerine dönen erkekler, bıraktıkları işlerini kadınlardan geri aldı ve bu gelişme, kadınların yeniden evlerine dönmeleriyle sonuçland1. Zihnioğlu (2003), dönemin kadın dergilerinde kadınların söz konusu gelişmelerden duydukları hoşnutsuzluğu sıklıkla dile getirmiş olduklarını tespit eder.

Türk Kadınlar Birliği, Cumhuriyet'in 1923 yılında kurulmasından yalnızca bir sene sonra, bu tarihsel fonda, seçme ve seçilme hakları gibi kadınların siyasi hak taleplerine ilişkin çalışmalar yürütmek amacıyla kurulur. TKB kadınların taleplerini millet meclisine taşıma ve siyasi gündem oluşturma anlamında birçok başarıya imza atar. Ancak yeni Cumhuriyet, kadınlardan yönelen muhalefete olumlu yaklaşmaz. Üzerindeki siyasi baskılara dayanamayan TKB, siyasi hak taleplerinden vazgeçmek durumunda kalır ve sonrasında bir yardım kuruluşuna dönüştürülür. Kadınların vatandaşlık haklarının tanınmasını izleyen süreçte ise birlik, kendi üyeleri tarafından 1935 yılında feshedilir (Zihnioğlu, 2003: 256-58). ${ }^{7}$

7 Bugün faaliyette olan Türk Kadınlar Birliği 1951 senesinde kurulmuş, 1954 yılında da, Bakanlar Kurulu kararıyla "Kamu Yararına Çalışan Dernek" statüsünü kazanmıştır. Derneğin üyeleri, Nezihe Muhiddin tarafından 1924 yılında kurulan birliği sürdürme 
Kadınların söz konusu süreçteki rolleri bundan ibaret olmamıştır. Kadınlar, Türk modernleşmesinde ve dolayısıyla onunla iç içe ilerleyen ulus-devletleşme sürecinde önemli rol oynarlar. Ancak kadınların söz konusu süreçte oynadıkları rolü, modernleşme tarihini yazan kaynaklarda görmek mümkün değildir (Sancar, 2014). Çok sayıda kadının, hem Milli Mücadele döneminde hem de Cumhuriyet'in kuruluşunda yer almış ya da kurucu kadroları desteklemiş olmalarına rağmen resmi kaynaklarda kadınlardan çok az bahsedilir. Bir yandan ulusal mücadeleye destek olurken bir yandan da kadınların siyasi hak talepleri konularında mücadele etmiş olmalarına rağmen Cumhuriyet'in ilk Anayasası, siyasi hakları kendilerine tanımamış, yeni Cumhuriyet kadınları erkeklerle eşit vatandaş statüsünde saymamıştır (Sancar, 2014: 112-113). Sancar'in ifadeleriyle,

Yeni rejimin devlet yönetim kadrolarında bir tek kadına bile yer verilmemesi kadın hakları söyleminden ideolojik, politik ve kültürel olarak ciddi bir kopuşun göstergesi olarak kabul edilmelidir. (...) Bunun yerine modernleşmenin sembolü olmaları istenen kadınlar için ayrı kamusal görünürlük konumları sunulmuş. Erkeklerle siyasal alanda aynı siyasal mücadelelere katılan kadınların ulus-devlet kurulduktan sonra onun yönetimine katılmalarının sakıncalı bulunması modern siyaset anlayışında bugüne kadar etkisini sürdüren bir cinsiyetçi sakatlanma nedeni olmuştur (2014:113).

Modern ulus-devletin ideolojik kadrosunu oluşturan milliyetçi hareket içinde temel rol oynamalarına rağmen yönetim kadrolarında yer almalarına izin verilmeyen iki önemli ismin, Halide Edip ve Nezihe Muhiddin'in yaşadıkları, kadınların ulus-devlet inşasından ve kurumsallaşma sürecinden nasıl dışlandıklarını gösteren en somut örneklerdir (Zihnioğlu, 2003; Durakbaşa, 2010). Zihnioğlu, sözü edilen süreçte kadınları dışlayanları "Cumhuriyet'in erkek kurucular kuşağının hükümeti/siyasetçileri”; dışlananları ise "cumhuriyetçiliği benimseyen, Osmanlı Türk kadın hareketinin feminist eylemci ve düşünürleri” olarak tarif eder (2003: 19). İnşa edilmekte olan ulus-devletin kurmak istediği toplumsal cinsiyet rejiminin niteliği de bu çatışmada, oluşturulan dışlama süreç ve mekanizmalarında kendini göstermektedir.

amacında olduklarını belirtmektedirler (Gazioğlu, 2010). 
Kadınların seçme ve seçilme hakkı tartışmaları, 1934 senesinden önce de birkaç defa meclis gündeminde yer alır. Ancak kadınlar bu haklara ulaşmak için takvimin 5 Aralık 1934 tarihini göstermesini beklemek durumunda kalırlar. İlginç olan nokta şudur; kadınlara seçme ve seçilme hakkının tanındığı son tartışmada, konuya ilişkin daha önceki tartışmalarda karşılaşılan sert muhalefetten eser yoktur. Örneğin, 1923 yılının Nisan ayında mecliste "İntihâb-1 Mebusan Kanunu" görüşülürken kadınların seçme hakkı gündeme gelmiş ancak yoğun itirazlar sonucunda hakkın tanınması kabul edilmemiştir (Sezer, 1998). Bu tartışmaların içinde kadınların yeterli siyasi olgunluğa sahip olmadıkları ve ancak böylesi bir olgunluğa erişmelerinin ardından bu tür haklara haiz olabileceklerine dair argümanlar dahi yer alabilmiş ve kadınlara, siyasi yeterliliğe sahip olana değin beklemelerinin tavsiye edildiği olmuştur (Ünal, 2014). Hatta seçme ve seçilme hakkını meclisin gündemine taşımak isteyen kimi vekillerin söz almaları, diğer vekiller tarafından çeşitli şekillerde protesto edilmiştir. Örneğin, Tunalı Hilmi Bey’in, kadınların siyasi haklarının tanınması gerektiğine dair konuşması diğer vekillerce ayaklarını yere vurmak suretiyle sık sık kesilmiştir (TBMM ZC, C.1, İ. 7, ss. 322- 344).

Öte taraftan siyasi hakların tanınıp tanınmamasına dair 5 Aralık tarihli son değerlendirmede bu haklar, ilgili meclis tutanaklarının gösterdiği üzere, vekillerden gelen coşkulu bir kabulle tanınır. Meclise hâkim olan bu coşku, dönemin Konya Milletvekili Refik Koraltan'ın sözlerinde en net ifadesine kavuşmaktadır: "Baylar, şimdi onayımıza verilen bu kanunla Türk kadını değeri olan yeri alıyor (Alkışlar). Büyük ulusun yüksek kurultayı, bu gün Yüksek Kurtarıcının önderliğinde vereceği kararla büyük inkılâbın değerli kıldığı büyük işlerden birisini daha yapmış olacaktır. Baylar, sevinelim, Ögünelim, çünkü Türküz; çünkü Atatürkümüz vardır (Şiddetli alkışlar). Ulus var olsun. Atatürk sağ olsun (Alkışlar)." (TBMM ZC, C. 2, İ. 12, s. 83). Böylelikle "adil olmanın verdiği övünç" söylemine dair önemli bir örnek olarak Refik Koraltan'ın sözleri, tutanaklardaki yerini almaktadır.

Tartışmalarda öne çıkan ve yukarıda tarif edilen anlayış ve algıyla bağlantılı olan bir diğer söylem, hakların kadınlara verildiği şeklindeki söylemdir. Yine örneğine sıkça rastlanan bir kabul olarak bu söylem en net ifadelerine İsmet İnönü'nün cümlelerinde kavuşmaktadır: "Yakın geleceklerde, Türk Devletinin ve Türk ulusunun geniş 
kudretlerinin sırrı anlaşıldığı zaman, bunun başında, ilk günden beri Türk inkılâbının Türk kadınına verdiği haklar esaslı bir delil olarak ileri sürülecektir ( Okay sesleri, alkışlar ). Bizim bu gün yaptığımız bu teşebbüs, Büyük Millet Meclislerinin ve Türk inkılâbının yıllardan beri güttüğü siyasanın tam bir varanıdır. İnkilâpçılar, yüce heyetiniz, bunu, yurdun ve ulusun menfaati ve iyiliği namına anlayışlarımızın yeni bir belgesi olarak gösterip övünebiliriz.” (TBMM ZC, C. 2, İ. 12, s. 83) "Bizim verdiğimiz haklar" ifadesine yapılan vurgunun daha baskın olduğu bir diğer örnek, Refik Koraltan'ın sözlerindedir: "Her hangi bir ülkede kadınlar bu kadar ağır imtihanlar geçirmişse, orada da kadınlar elbette bizim kanunen verdiğimiz haklara kavuşacaktır." (TBMM ZC, C. 2, İ. 12, s. 83) Koraltan, kadın haklarının verilmesinin meclis kararına bırakılmış olmasının öneminden bahseder ve şöyle ekler: “(b) üyük ulusun yüksek kurultayı, bu gün Yüksek Kurtarıcının önderliğinde vereceği kararla büyük inkılâbın değerli kıldığı büyük işlerden birisini daha yapmış olacaktır." (TBMM ZC, C. 2, İ. 12, s. 83) Övünç söylemi ile iç içe geçen ifadelerinde Koraltan, meclisin aldığı kararda Atatürk'ün etkisine de böylelikle değinmiş olmaktadır. Şebin Karahisar milletvekili Sadri Maksudi de benzer içerikte bir konuşma yapar ve vekillerin, kadınlara oy hakkı vereceğinden şüphesi olmadığını ekler (TBMM ZC, C. 2, İ. 12, s. 83).

Kadınların, ülkelerinin bağımsızlık mücadelelerinde yer alarak eşit vatandaşl1k statüsünü hak etmiş oldukları şeklindeki söylem de, kadınların seçme ve seçilme haklarına dair tartışmada en sık rastlanan söylemdir. Bunlardan biri en somut örneğine İsmet İnönü’nün şu ifadelerinde kavuşmaktadır: "(B)ir memlekette ki, yurdun her tarafı istilâya uğradığı zaman, kadınlar ateş altında erkeklerle beraber omuz omuza çalışırlar, memleketin geri kalan kısmını korumak ve beslemek için tarlanın kara toprağından yiyecek çıkarmağa çalışırlar, elbette bu mevcudiyetlerin yurdun her köşesinde ve her tabakasında söz söylemeğe hakları vardır" (TBMM ZC, C. 2, İ. 12, s. 82). Aşağıdaki örneklerin sayıca çokluğu da, söylemin, dönemin meclisine hâkimiyeti konusunda fikir vermektedir. Örneğin İsmet İnönü şöyle der: "Şart, evvelâ kadınların, bizim kadınlığıma gibi çetin imtihanlardan geçmiş ve daha çok çetin imtihanları göğüslemek için bileklerinde, akıllarında ve yüreklerinde kuvvet olduğunu ispat etmiş olmalarıdır." (TBMM ZC, C. 2, İ. 12, s. 83). Benzer şekilde Refik Koraltan şöyle söyler: "Türk kadınını 
acun tanır. Erkekten hiç bir savaşta geri kalmamış, onunla omuz omuza yürümüş, onunla tarlada beraber çalışmıştır. Ekin kaldırırken, ineğini sağarken, yavrusuna ninni söylerken dahi erkekten ayrılmayan Türk kadını ulus işlerinde de yüksek varlığını göstermiştir.” (TBMM ZC, C. 2, İ. 12, s. 83)

\section{Sonuç}

$\mathrm{Bu}$ makalenin incelediği 1934 yılı meclisinde kadın vekil yoktur ve 1935 yılındaki seçimlere kadar da olmayacaktır. Dolayısıyla kadınların siyasi haklarına dair 1934 yılı tarihli tartışmalar, tıpkı kendisinden öncelikler gibi kadınların olmadığı bir ortamda gerçekleşmiştir. Bu durumun kadınlar açısından neden olduğu en büyük sakınca, kadınların var olamadıkları, kendi taleplerini dile getiremedikleri bir ortamda, başkalarının onların yerine hak talep etmesi için beklemek zorunda kalmalarıdır. Gerçekten de siyasi hak talebi etrafında uzun zamandır mücadele etmekte olmalarına rağmen bu talebin ülkenin gündemine alınması ancak erkeklerden mürekkep bir topluluğun, yani meclisin kararına bağlı kalmıştır. Tartışmanın meclis gündemine alınması da sorunu çözmemiş, bu sefer de söz konusu taleplerin kadın bakış açısından tartışılması gereği/sorunu gündeme gelmiştir.

Makale, ulus-devletin kadın hakları ile gerilimli ilişkisi bağlamında, genç Türkiye'nin "kadınsız" meclisinde, kadınların seçme ve seçilme haklarına dair tartışmaların hangi bağlamlarda yer aldığına bakmış ve tartışmalara egemen olan söylemlere odaklanmıştır. Buna göre makalenin ulaştı̆̆1 sonuçları şöyle özetlemek mümkün görünmektedir: Ulus-devlet, toplumsal cinsiyet açısından tarafsız bir siyasi birim değildir. Genç Türkiye'nin toplumsal cinsiyete ilişkin tutumu da bu durumun bir yansımasıdır. Türkiye'de ulus-devletin, benimsemiş olduğu toplumsal cinsiyet rejimini meşrulaştırmak için başvurduğu söylemler ile post-kolonyal söylem arasında paralellikler mevcuttur. Dönemin meclis tutanaklarından takip edildiği üzere kadınların, ulusal kurtuluş mücadelesine katıldıkları için siyasal hakları hak ettikleri yönündeki söylem, konuya ilişkin post-kolonyal söylemle önemli benzerlikler taşımaktadır. Kadınların eşit vatandaşlık taleplerini görmezden gelen ve siyasal hakların "tanınmasından" ziyade "verilmesi" vurgusuyla ön plana çıkan söylem, genç Türk ulus-devleti ile post-kolonyal devletlerin ortaklaştıkları önemli noktalardan biridir. Ulus-inşasından 
dışlanmış olmalarına karşın kadınların, devlet tarafından -bir anlamdasahiplenilerek, rejimi benimsemeleri sağlanmıştır. Bu süreçte de yine Türkiye'deki ulus-devlet inşası sürecinde sömürgecilik sonrası dönemin izleri görülmektedir. 


\section{Kaynakça}

Agozino, B. (2014). Revolutionary African women: A review essay of the women's war of 1929: A history of anti-colonial resistance in Eastern Nigeria. The Journal of Pan African Studies, 7 (3), 282-293.

Alpaslan, E. (2013). 1923-1950 dönemi Türkiye Büyük Millet Meclisi'nde Maraş milletvekilleri ve siyasi faaliyetleri. Yayınlanmamış Doktora Tezi. Kahramanmaraş Sütçü İmam Üniversitesi, Sosyal Bilimler Enstitüsü, Tarih Anabilim Dalı.

Anderson, B. (1991). Imagined communities: Reflections on the origin and spread of nationalism. London: Verso.

Anderson, B. (2007). Hayali cemaaatler. İstanbul: Metis Yayınc1lık.

Bayrak, B. (2007). Meclis tutanakları 1şığında Türk Medeni Kanunu değişikliği. Hukuk Gündemi, 8, 53-56.

Chadya, J. M. (2003). Mother politics: Anti-colonial nationalism and the woman question in Africa. Journal of Women's History, 15 (3), 153-157.

Chatterjee, P. (1994). Whose imagined community? Mapping The Nation (ss. 214-225). London: Verso.

Chaudhuri, M. (1999). Gender in the making of the Indian Nation-State. Sociological Bulletin, 48, 113-133.

Connell, R. W. (1987). Gender and power: Society, the person and sexual politics. Cambridge: Polity Press.

Cook, J. A., \& Fonow, M. M. (1990). Knowledge and women`s interests: Issues of epistemology and ethodology in feminist research. Feminist research method: Exemplary reading in the social sciences (ss. 69-93). London: West Press.

Durakbaşa, A. (2000). Halide Edib, Türk modernleşmesi ve feminizm. İstanbul: İletişim Yayınları.

Enloe, C. (1989). Bananas, beaches and bases - Making feminist sense of international politics. Berkeley: University of California Press.

Gazioğlu, E. (2010). Mobilizing for women's organizations women activists' perceptions of and women's organizations in Turkey. Yayınlanmamış Doktora Tezi, University of York, Centre For 
Women's Studies.

Enloe, C. (2013). Feminizm, milliyetçilik ve militarizm. Vatan millet kadınlar (ss. 189-212). İstanbul: İletişim Yayınları.

Kaminsky, A. (2007) Another site of globalization: "Woman" as symbol of nation and diaspora in Martin (Hache). Gender and globalization in Latin America : 10th anniversary of the nordic network haina (1996-2006) (ss. 165-170). Göteborg University Press: Göteborg.

Jaggar, A. M. (2008). The social sciences. Just methods: An interdisciplinary feminist reader (ss. 34-39). London: Paradigm Publishers.

Leonhardt, A. (2013). Between two jailers: Women 's experience during colonialism, war, and independence in Algeria. Anthos, 5 (1), 42-54. Erişim tarihi: 12 Haziran 2015, http://pdxscholar.library. pdx.edu/cgi/viewcontent.cgi?article $=1031 \&$ context $=$ anthos

Mayer, T. (2000). Gender ironies of nationalism: Setting the stage. Gender ironies of nationalism: Sexing the nation (ss. 1-22). London: Routledge.

McClintock, A. (1995). Imperial leather: Race, gender and sexuality in the colonial contest. London: Routledge.

McDowell, L. (1999). Gender, identity and place: Introducing feminist geographies. Minneapolis: University of Minnesota Press.

McClintock, A. (1993). Family feuds: Gender, nationalism and the family. Feminist Review, 44, 61-80.

Omar, K. (2004). National symbolism in constructions of gender: Transformed symbols in post-conflict states. Seton Hall Journal of Diplomacy and International Relations, 49-67.

Phillips, A. (1995). Demokrasinin cinsiyeti. İstanbul: Metis Yayıncılık.

Riedner, R. (2013). Lives of in-famous women: Gender, political economy, nation-state power, and persuasion in a transnational Age. JAC: A Journal of Rhetoric, Culture \& Politics, 33, 645-670.

Sancar, S. (2014). Türk Modernleşmesinin cinsiyeti - Erkekler devlet kadınlar, aile kurar. İstanbul: İletişim Yayınları.

Sezer, A. (1998, Özel sayı). Türkiye'deki ilk kadın milletvekilleri ve meclisteki çalışmaları. Atatürk Araştırma Merkezi Dergisi, XIV: 
42, 889-905.

Unanimous. (1776) Declaration of Independence. American Congress. Erişim tarihi: 10 Mayıs 2015, http://www.constitution.org/ us_doi.pdf

Ünal, S. (2014). Türk kadınının seçme ve seçilme hakkını kazanmas1 ve basin. Turkish Studies - International Periodical For The Languages, Literature and History of Turkish or Turkic Volume, 9 (7), 525-559.

Vickers, J. (2008). Gendering the hyphen: Gender dimensions of modern nation-state formation in Euro-American and Anti- and post-colonial contexts. Gendering the nation-state Canadian and comparative perspectives (ss. 21-45 ). Vancouver: UBC Press.

Westkott, M. (1990). Feminist criticism of the social sciences. Feminist research method: Exemplary reading in the social sciences (ss.58-69). London: West Press.

Yaramış, F. (2012). Türkiye Büyük Millet Meclisi I. Döneminde (23 Nisan 1920-1 Kasım 1922) çıkarlan adli, sosyal, kültürel kanunlar ve bu kanunların müzakerelerinde muhalefet. Yayınlanmamış Yüksek Lisans Tezi. Ahi Evran Üniversitesi, Sosyal Bilimler Enstitüsü, Tarih Anabilim Dalı.

Zihnioğlu, Y. (2003). Kadınsız inkılap Nezihe Muhiddin, Kadınlar Halk Fırkası, Kadın birliği. İstanbul: Metis Yayıncılık.

Zürcher, E. J. (2004). Modernleşen Türkiye'nin tarihi. İstanbul: İletişim Yayınları.

\subsubsection{Tarihli Meclis Tutanakları}

TBMM ZC, C. 2, İ. 12, s. 83.

TBMM ZC, C. 2, İ. 12, s. 82.

TBMM ZC, C. 2, İ. 12, s. 83.

TBMM ZC, C. 2, İ. 12, s. 83.

TBMM ZC, C.1, İ. 7, ss. 322- 344.

\subsubsection{Tarihli Mektup}

TBMM ZC, c.25, İ. 4, s. 90. 